\title{
BIOAEROSOL AND SMOG AS DETERMINANTS OF HUMAN POPULATION HEALTH
}

\section{BIOAEROZOL I SMOG JAKO DETERMINANTY ZDROWIA POPULACJI LUDZKIEJ}

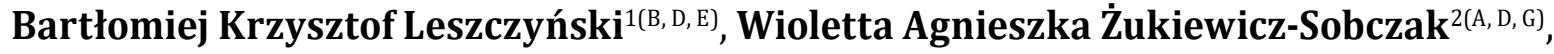 Paweł Sobczak $^{3(\mathrm{~A}, \mathrm{E}, \mathrm{F})}$, Francesco Santoro ${ }^{4(\mathrm{~A}, \mathrm{D})}$}

\author{
${ }^{1}$ Emergency Department, Miedzylesie Specialist Hospital in Warsaw, Poland \\ ${ }^{2}$ Pope John Paul II State School of Higher Education in Biała Podlaska, Poland \\ ${ }^{3}$ Department of Food Engineering and Machines, Faculty of Production Engineering, \\ University of Life Sciences in Lublin, Poland \\ ${ }^{4}$ Department of Agricultural and Environmental Science, University of Bari Aldo Moro, Italy
}

Authors' contribution Wkład autorów:

A. Study design/planning zaplanowanie badań

B. Data collection/entry zebranie danych

C. Data analysis/statistics dane - analiza i statystyki D. Data interpretation interpretacja danych E. Preparation of manuscript przygotowanie artykułu F. Literature analysis/search wyszukiwanie i analiza literatury G. Funds collection zebranie funduszy

Tables: 0

Figures: 0

References: 28

Submitted: 2019 May 7

Accepted: 2019 Jun 17

\section{Summary}

When asked to describe air pollution, the average person will invariably mention the word "smog". Although the term is often poorly understood, social awareness of it is much higher than just a few years ago. In the era of globalization, it has become clear that smog goes beyond dust and gas pollution and encompasses the microbiological purity of the air. This is due, among other things, to the fact that the human body may not only be a reservoir but also an emitter of microbiological particles dangerous to health and life. According to Górny, SCMB (Harmful Microbiological Factors) are easier to aerosolize compared to other air pollutants [1]. It highlights the risk of infectious diseases from abroad, including allergic disease entities. It also emphasizes the close relationship between various types of air pollution.

Keywords: bioaerosol, allergic diseases, air pollution, smog

\section{Streszczenie}

Nie sposób nie odnieść wrażenia, iż po zapytaniu przechodnia o zanieczyszczenia powietrza, odpowie „smog”. Poprzez działanie szeroko rozumianego mainstreamu, świadomość społeczna w dziedzinie smogu jest zdecydowanie wyższa, aniżeli jeszcze kilka lat temu. Jednak tym, co budzi obawy w dobie globalizacji, jest zagadnienie nie tyle smogu (zanieczyszczenia głównie pyłowe i gazowe), co czystości mikrobiologicznej powietrza. Wynika to między innymi z faktu, iż organizm ludzki może być nie tylko rezerwuarem, lecz także źródłem emisji niebezpiecznych dla zdrowia i życia cząsteczek mikrobiologicznych. Według Górnego, SCMB (Szkodliwe Czynniki Mikrobiologiczne) w porównaniu do innych zanieczyszczeń powietrza są łatwiej transportowane drogą aerozolu [1]. Otwiera to temat tzw. chorób zawleczonych z zagranicy, włączając w to alergiczne jednostki chorobowe. Jednocześnie ukazuje ścisły związek między różnego typu zanieczyszczeniami powietrza.

Słowa kluczowe: bioaerozol, choroby alergiczne, zanieczyszczenia powietrza, smog

\section{Introduction}

When asked to describe air pollution, the average person will invariably mention the word "smog". Although the term is often poorly understood, social awareness of it is much higher than just a few years ago. In the era of globalization, it has become clear that smog goes beyond dust and gas pollution and encompasses the microbiological purity of the air. This is due, among other things, to the fact that the human body may not only be a reservoir but also an emitter of microbiological particles dangerous to health and life. According to Górny, SCMB (Harmful Microbiological Factors) are easier to aerosolize compared to other air pollutants [1]. It highlights the risk of infectious diseases from abroad, including allergic disease entities. It also emphasizes the close relationship between various types of air pollution.

Leszczyński BK, Żukiewicz-Sobczak WA, Sobczak P, Santoro F. Bioaerosol and smog as determinants of human population health. Health Prob Civil. 2019; 13(3): 233-237. https://doi.org/10.5114/hpc.2019.86117

Address for correspondence / Adres korespondencyjny: Wioletta Agnieszka Żukiewicz-Sobczak, Pope John Paul II State School of Higher Education, Sidorska 95/97, 21-500 Biała Podlaska, Poland, e-mail: wiola.zukiewiczsobczak@gmail.com

ORCID: Wioletta Agnieszka Żukiewicz-Sobczak https://orcid.org/0000-0002-0142-5102, Paweł Sobczak https://orcid.org/0000-0003-2167-1498,

ORCID: Wioletta Agnieszka Zukiewicz-Sobczak https://orcid.org
Francesco Santoro https://orcid.org/0000-0001-9115-8265

Copyright: ( ) Pope John Paul II State School of Higher Education in Biała Podlaska, Bartłomiej Krzysztof Leszczyński, Wioletta Agnieszka Żukiewicz-Sobczak, Paweł Sobczak, Francesco Santoro. This is an Open Access journal, all articles are distributed under the terms of the Creative Commons Attribution-NonCommercialShareAlike 4.0 International (CC BY-NC-SA 4.0) License (http://creativecommons.org/licenses/by-nc-sa/4.0/), allowing third parties to copy and redistribute the material in any medium or format and to remix, transform, and build upon the material, provided the original work is properly cited and states its license. 


\section{Aim of the work}

This work aims to examine the subject of air pollution and allergic inhalation diseases that can be induced by smog and microbiological pollution of the air. In addition, we wish to draw attention to the insufficient consideration given to both topics, particularly the interaction between them, in public discussions.

\section{Source and emission mechanism of atmospheric air biological pollutions}

The air carrying pollutants, known as the dissipative phase, and the colloidal mixture of materials in the air, known as the dispersed phase, form the bioaerosol world. Gołofit-Szymczak and Skowron highlight that dust suspended in the air forms a kind of smog in Poland and London [2].

House dust can be of plant, animal and mineral origin as well as dust P10 and P2.5 [2]. Zawisza and others have discussed house dust as a mixture of allergens specific to each household and work environment: metabolites Dermatophagoides pteronyssinus - European house dust mite (especially three storage species: Tyrophagus putrescentiae, Acarus siro and Lepidoglyphus destrruktor), fungal spores, even mold [3, 4], hair and epidermis. This is relevant because, as emphasized by Yang's research, society increasingly spends time in closed rooms [5]. Metabolites of microorganisms in the air are another major biological allergen. Of these, mite metabolites are most often mentioned in Poland, while in the US and Germany metabolites are often identified from cockroaches (Periplaneta americana and also Blatella germanica) $[6,7]$.

About 8-11 million Poles are exposed to micro-toxins of mold fungi (strong allergens) that have settled on finishing building materials $[8,9]$. Biologically active components of bioaerosols include pathogenic enzymes and entero- and endotoxins including mytotoxins. In addition, the scaly epidermis in the form of dandruff, flower pollen and the remains of plant organisms are frequently found in the air [7].

According to Ann and colleagues, the most common determinants of immunological diseases of the respiratory system are mycelium fragments as well as fungal spores, protozoa and viruses as well as cell fragments and whole bacterial cells [10].

\section{Easiness of the spread of biological allergens}

Particles deposit in the airways depending on the age-related vital capacity of the lungs [1]. The smallness of mold spores permits them to deposit extensively $[11,12]$. This is true for mold spores most commonly found in rooms such as Aspergillus, Alternaria, Candida, Cladosporium and Penicillium [13]. Another easy-to-spread allergen is the cat-derived Fel d1. Its high concentration, of course, occurs in rooms that cats live. However, its effect is so strong that only a small amount is sufficient to induce an immune response [14]. As people can be a major source of emissions of biological pollutants and also their incubator [15], cat allergens can also be found in buildings like cinemas, hospitals and homes without cats.

Dog allergens such as Can f1 and Can f2 are less clinically significant, although their occurrence is just as common as Fel d1 allergens. All of these animal allergens, as well as those from rodents and pests, should be considered as part of internal air pollution [14]. Pałczyński also discussed volatiles as being divided into animal and vegetable proteins, organic and inorganic chemicals. As airing of rooms does not have a positive effect on their microbiological purity [15], we discuss the range of factors involving air quality when mixing outdoor and indoor air. Sulfur oxides, nitrogen and carbon are also important components of smog [16].

\section{Acts of legislation of air pollution level normalization}

The first Polish standard specifying acceptable levels of biological pollution was established at the end of the $19^{\text {th }}$ century by Odo Bujwid, the Polish bacteriologist and pioneer of therapeutic prophylaxis. On the basis of his own research, he calculated the maximum amount of bacteria that could be present in the air. His calculation of "50 bacteria in a liter" became the accepted upper limit [15]. Krzysztofik in the 1970s measured the number of hemolytic microorganisms and the total number of fungi in the air and created the scientific foundation for the writing of the first acts of legislation. They addressed the following:

- "guidelines and general provisions regarding the sampling of atmospheric air"

- "methods of microbiological testing of air" [17],

- "determination of the number of bacteria and microscopic fungi in the atmosphere when sampling by aspiration and sedimentation" $[18,19]$. 
More recently, after Poland acceded to the EU Community, through the amendment of the Labor Code and the Regulation of the Minister for Health Protection from 2005, Directive 2000/54/EC also became applicable. This legislation's main aims are:

- introduction of rules of conduct "on the protection of workers from the risks related to exposure to biological agents at work",

- in the matter of health prevention and elimination of health determinants, the obligation to ensure proper protection of employees by the employer,

- and recommendation for conducting auxiliary tests of indicator microorganisms [20].

\section{SCMB definition}

The Regulation of the Minister of Health of 2005 on "harmful biological factors for health in the work environment and health protection for workers professionally exposed to these factors" defines bioaerosol as "microorganisms (including genetically modified), cell cultures, including those carried out in laboratory conditions and cell cultures derived from multicellular organisms, internal human parasites, capable of causing infection, allergy or a toxic reaction either directly or through the structures and substances they produce, as well as cellular and cell-free organisms capable of replication or transfer of genetic material" [21]. The definition is quite wide and useful, as it takes into account many health determinants of the population.

\section{Influence of SCMB and smog on human health}

Adult humans consume up to 20,000 cubic meters of air every day and therefore have a high risk of airborne pathogens entering the respiratory tract. This is particularly true for diseases like atopic asthma, which makes one vulnerable to a whole range of allergy-mediated diseases [22].

Respiratory mixtures contain the etiological factors of numerous immunological diseases [23]. It is also likely that the number of SCMB will continue to increase as our knowledge grows [24].

Among the viral factors, pathogens for the following diseases are common in the air: influenza, chickenpox, meningitis (which may be a complication of the mumps, when an adult suffers), mononucleosis, rubella and shingles.

Diseases from Streptococcus and Staphylococci species are also common [15]: inflammation of the bronchial tubes and lungs, rhinitis, alveolitis, pulmonary tuberculosis and pertussis.

Fungal diseases also have pathogens frequently found in the air: lungs and their fungal inflammation, bronchus mycosis, mucormycosis, cryptococcosis and aspergillosis [9].

According to the European air quality monitoring company Airly, diseases such as cancer, allergic asthma, respiratory failure, and immunodeficiency can be the result of a long exposure to smog. For the immediately occurring symptoms, netography measures difficult gas exchange, a consequence of breathing made difficult by thick air smog [25]. The Global Initiative for Asthma reports that exposure to the above-mentioned factors leads to the development of the atopic form of bronchial asthma [26]. In the report of the Department of Analysis and Strategy of the National Health Fund, we find: that "the potential cause of the increase in deaths in January 2017 is abrupt deterioration in air quality, which can cause violent health consequences in particularly vulnerable people, including the cardiovascular system" [25, 26, 27, 28].

\section{Conclusions}

1. The environment has a real impact on the bioaerosol hygiene.

2. The qualitative and quantitative composition of bioaerosol may affect the occurrence of disease symptoms in hypersensitive people.

3. The public is unaware of the dangers of environmental bio-aerosol pollution.

4. The human population should be made aware of the health risks resulting from exposure to toxic bioaerosol issues.

\section{Summary}

Currently, two types of smog are distinguished, a dominance of gases in the case of California smog (Los Angeles smog type) and dust in the case of the London type [25]. To these should be added smog associated with microbiological factors. Biological pathogens may be the most dangerous element of internal and external air. 
Due to the modern age's ease in crossing borders for work or tourism, the threat to human health from transport of microbial pathogens from other continents has never been greater. This emphasizes the importance of paying global attention to the role of SCMB (Microbial Factors) in the dispersed phase of air. Therefore, air pollution or smog must be understood in a wider sense $[25,26,27,28]$.

\section{References:}

1. Górny RL. [Biohazards: standards, guidelines, and proposals for threshold limit values]. PiMOAP. 2004; 3(41): 17-39 (in Polish).

2. Gołofit-Szymczak M, Skowroń J. [Microbiological contaminants in office buildings]. Bezpieczeństwo Pracy. 2005; 3: 29-31 (in Polish).

3. Zawisza E, Lipiec A. [Fungal allergens]. In: Zawisza E, Samoliński B., editors. [Allergic diseases]. Warszawa: PZWL; 2008 (in Polish).

4. Pastuszka JS, Paw UKT, Lis DO, Wlazło A, Ulfig K. Bacterial and fungal aerosol in indoor environment in Upper Silesia, Poland. Atmospheric Environment. 2000; 34(22): 3833-3842. https://doi.org/10.1016/s1352-2310(99)00527-0

5. Yang W, Sohn J, Kim J, Son B, Park J. Indoor air quality investigation according to age of the school building in Korea. Journal of Environmental Management. 2009; 90(1): 348-354. https://doi.org/10.1016/j.jenvman.2007.10.003

6. Law AKY, Chau CK, Chan GYS. Characteristics of bioaerosol profile in office buildings in Hong Kong. Building and Environment. 2001; 36(4): 527-541. https://doi.org/10.1016/s0360-1323(00)00020-2

7. Arganovski IE, Arganovski V, Reponen T, Willeke K, Grinshupun SA. Development and evaluation of a new personal sampler for culturable airborne microorganisms. Atmospheric Environment. 2002; 36(5): 889898. https://doi.org/10.1016/s1352-2310(01)00488-5

8. Zyska B. [Biological hazards in the building]. Warszawa: Wydawnictwo Arkady; 1999. p. 252 (in Polish).

9. Żukiewicz-Sobczak W, Sobczak P, Imbor K, Krasowska E, Horoch A, Wojtyła A, et al. [Fungal hazards in buildings and flats - impact on the human organism]. Med Og Nauk Zdr. 2012; 18(2): 141-146 (in Polish).

10. An HA, Mainelis G, You M. Evaluation of a high-volume portable bioaerosol sampler in laboratory and field environments. Indoor Air. 2004; 14(6): 385-393. https://doi.org/10.1111/j.1600-0668.2004.00257.x

11. Bonetta SA, Bonetta SI, Mosso S, Sampo S, Carraro E. Assessment of microbiological indoor air quality in an Italian office building equipped with an HVAC system. Environ Monit Assess. 2009; 161(1-4): $473-483$. https://doi.org/10.1007/s10661-009-0761-8

12. Menetrez MY, Foarde KK, Dean TR, Betancuort DA, Moore SA. An evaluation of the protein mass of particulate matter. Atmospheric Environment. 2007; 41(37): 8264-8274. https://doi.org/10.1016/j.atmosenv.2007.06.021

13. Skyberg K, Skulberg KR, Eduard W, Skåret E, Levy F, Kjuus H. Symptoms prevalence among office employees and association to building characteristics. Indoor Air. 2003; 13(3): 246-252.

https://doi.org/10.1034/j.1600-0668.2003.00190.x

14. Platts Mills TA, Vervolet D, Thomas WR, Aalberse RC, Chapman MD. Indoor allergens and asthma. Report of the Third International Workshop. J Allergy Clin Immunol. 1997; 100(6 Pt 1): 1-24.

15. Leszczyński BK. [Allergy and allergic diseases in the context of environmental bioaerosol hygiene] [master's thesis]. Biała Podlaska: Pope John Paul II State School of Higher Education; 2018 (in Polish).

16. Pałczyński C. [Allergic factors in the workplace]. Warszawa: Centrum Medyczne Kształcenia Podyplomowego w Warszawie; 2011. p. 107 (in Polish).

17. Polish Committee for Standardization. PN-89/Z-04111/01 - [Air purity protection. Microbiological testing. General provisions and scope of the standard]. 1989 (in Polish).

18. Polish Committee for Standardization. PN-89/Z-04111/02 - [Air purity protection. Microbiological testing. Determination of the number of bacteria in the atmospheric air (imission) with sampling by aspiration and sedimentation]. 1989 (in Polish).

19. Polish Committee for Standardization. PN-89/Z-04111/03 - [Air purity protection. Microbiological testing. Determination of the number of fungi in the atmospheric air (imission) with sampling by aspiration and sedimentation]. 1989 (in Polish).

20. Directive 2000/54/EC of the European Parliament and of the Council of 18 September 2000 on the protection of workers from risks related to exposure to biological agents at work. Official J Eur Communites. L. 262/21. Brussels; 2000. 
21. [Ordinance of the Minister of Health of 22 April 2005 on biological factors harmful to health in the working environment, and health protection for employees subject to these factors (Journal of Law 2005, No. 81, item 716, as amended: Journal of Law 2008, No. 48, item 288)] (in Polish).

22. Chmiel MJ, Frączek K, Grzyb J. [The problems of microbiological air contamination monitoring]. Woda Środowisko - Obszary Wiejskie. 2015; 15(1): 17-27 (in Polish).

23. Dutkiewicz J, Górny RL. [Biological factors hazardous to human health: classification and criteria of exposure assessment]. Medycyna Praktyczna. 2002; 53(1): 29-39 (in Polish).

24. Dutkiewicz J, Śpiewak R, Jabłoński L, Szymańska J. [Biological factors of occupational hazard. Classification, exposed occupational groups, measurements, prevention]. Lublin: Ad Punctum; 2007. p. 160 (in Polish).

25. Airly [Internet]. Kraków: Airly Sp. z o.o. [Smog - definitions, effects and causes] [cited 2019 April 3]. Available from: https://airly.eu/pl/smog-definicja-skutki-i-przyczyny (in Polish).

26. NHLBI/WHO. [Global Initiative for Asthma (GINA). NHLBI/WHO Report]. Medycyna Praktyczna. 2002; (special issue): 6 (in Polish).

27. Departament Analiz i Strategii, Narodowy Fundusz Zdrowia. [Analysis of the causes of the increase in the death rate in Poland in 2017] [Internet]. Warszawa: Narodowy Fundusz Zdrowia [cited 2019 April 2]. Available from: https://www.nfz.gov.pl/download/gfx/nfz/pl/defaultstronaopisowa/349/41/1/raport_-zgony_w_2017_roku.pdf (in Polish).

28. Pascuzzi S, Santoro F. Analysis of possible noise reduction arrangements inside olive oil mills: a case study. Agriculture. 2017; 7(10): 88. https://doi.org/10.3390/agriculture7100088 